\title{
POST-CRISIS REALLOCATION OF GROWTH FACTORS
}

\author{
Edvard Jakopin* \\ Ministry of Finance - Department of National Development, Belgrade, Serbia
}

\begin{abstract}
The global recession has once again confirmed the economic principle stating that economic growth is not attainable unless there are continuous structural changes. The transition models of the reallocation of growth factors have demonstrated how inefficient they were when the recession struck. A research into the transitional growth of productivity has shown that productivity has primarily been based on an "intrasectoral profit", not on the so-called "reallocation effect". The entire area of SEE is faced with systemic macroeconomic imbalances primarily of a structural character. On the other hand, a comparative analysis of the reform experiences shows that transitional scores depend both on the speed of the undertaken reforms and the starting position. Studies have clearly demonstrated that sustainable economic growth was higher in those transition economies in which reforms were pursued faster than in those that pursued the strategy of incremental development. The crisis brought to the fore the significance of industrial policies that had been sidelined both in theoretical and practical terms. The focus of the post-crisis reallocation of growth factors in the new model of economic growth should be on structural changes steered towards the productive export sectors of the manufacturing industry.
\end{abstract}

Keywords: reallocation of growth factors, macroeconomic imbalances, development gap, post-crisis structural transformations

JEL Classification: O11, O47, L16, P21, O25, H62, J24

\section{INTRODUCTION}

The transition model based on the privatization of social assets is faced with the crisis of its legitimacy (Candeias, 2010). The recession blows have intensified the negative effects of the privatization process (huge unemployment, high social costs, and worse work conditions), changed the social interpretation

\footnotetext{
* Correspondence to: E. Jakopin, Ministry of Finance - Department of National Development, 11000 Belgrade, Serbia; e-mail: edvard@yubc.net
}

of privatization efficiency, and increased the critical distance. The further privatization of public goods is encountering a rather strong resistance. The crisis of the legitimacy of the privatization process stems from the widely-known example of the catastrophic privatization of the English railways, whose network would eventually be taken over by the state again. While transition countries are developing new models of the privatization of the state sector despite an everlarger number of annulled privatization processes, alternative concepts are being developed and specified throughout Europe. 
The transition area of SEE is faced with ever fiercer macroeconomic imbalances and the recession tide, and thus is striving to redefine its development models as fast as possible. The pre-crisis models of the reallocation of growth factors have created a big development gap and structural imbalances. All the post-crisis models of the reallocation of growth factors are based on industrial policies. Optimal industrial structures differ from the development degree of a country (Lin, 2010) as comparative advantages of various industries depend on a development stage (there are temporary and latent comparative advantages).

By exemplifying the Serbian economy, the research paper aims to: a) shed light on the trend and effects of macroeconomic and structural imbalances, b) discuss what its productivity growth is based on, i.e. whether its transition productivity growth is based on the "productivity effect" or "the reallocation effect", c) describe the quality of labor redistribution, and d) list the basic parameters of the post-crisis structural transformation and reallocation of the factors of the economic growth of Serbia's economy.

The main hypothesis presented in the paper is that the transformation model has not been conducive to the sectoral reallocation of resources and that the transition growth of the productivity of the Serbian economy has not been based on the reallocation effect, which is the main prerequisite for an adequate labor redistribution and structural changes. The methodological analytical instrument set is completed with representative macroeconomic indicators, the projection of economic growth is based on the quantifications of the new model of economic growth, while, for the purpose of carrying out an analysis of productivity, the wellknown Syrquin's methodology of productivity growth has been applied.

\section{ECONOMIC GROWTH AND MACROECONOMIC IMBALANCES}

The global economy is in a hazardous zone again. As different from 2009, this time the heart of the problem lies in the euro-zone. Namely, in many developed states of Europe, their economic growth is burdened with high public deficits and debts, rising market tensions, the intensification of financial turbulences, and an ever- weaker trust in the financial system, which all has an impact on investments and consumption, and results in urgent fiscal consolidation actions suppressing domestic demand and export activities.

Table 1 Estimated real growth of GDP

\begin{tabular}{lcccc}
\hline & 2010 & 2011 & 2012 & 2013 \\
\hline Euro-zone & 1,9 & 1,5 & 0,5 & 1,3 \\
EU-27 & 2,0 & 1,6 & 0,6 & 1,5 \\
USA & 3,0 & 1,6 & 1,5 & 1,3 \\
Japan & 4,0 & $-0,4$ & 1,8 & 1,0 \\
China & 10,3 & 9,2 & 8,6 & 8,2 \\
World & 5,0 & 3,7 & 3,5 & 3,6 \\
\hline
\end{tabular}

Source: EC, European Economic Forecast, 2011

The growth of domestic demand lags behind the GDP growth in the majority of developed economies in Europe. External demand is in decline in almost all of Europe and will probably continue to develop in accord with global slowing-down (IMF, 2011). The global financial markets are struck by the expansion of debt crises from European countries and thus the global economy is shifting to the trajectory of lower economic growth.

Problems of the largest economy in the world: The European Union is the largest economy in the world, its GDP being 16.2 billion dollars, which means it is bigger than both the American and the Chinese ones. However, $77 \%$ of the GDP is accounted for by services and only $20 \%$ by the industry. Besides, recession blows are caused by the deficit of the current account of the balance of payments, which is a problem that is getting worse day after day because of an ever-higher trade deficit. The EU has a huge trade deficit with China, which is a consequence of the EU's strategy to turn to a knowledge-based economy and exporting knowledge. So far, this tactic has lacked in successes while, on the other hand, the EU has lost its industry (Menciger, 2011).

Within the EU, a group of economies (Denmark, Germany, Poland, The Netherlands, Sweden, Switzerland, and Turkey) are practically out of 
the recession owing to a substantial growth of the manufacturing industry, the second group (Greece, Ireland, and Portugal) are in a deep debt crisis, while in the third group, the growth in 2011 was lower than the average growth prior to the crisis. Some of these economies have problems with the rising instability of the market and rising liabilities (Italy and Spain).

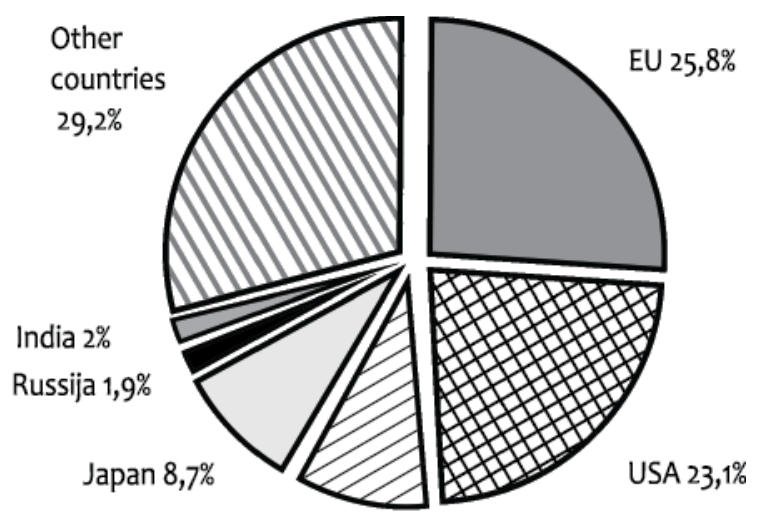

China $9,3 \%$

Graph 1 Structure of the global GDP 2010

Source: IMF, 2011

How the recession affects the transition economies of SEE: The economic recovery from the effects of the global crisis of 2008/2009 in the SEE countries started in 2010 only to continue in early 2011. However, since the second quarter of 2011, the economic situation has deteriorated and the recovery is uncertain because of turbulences in the euro-area that create huge risks in the SEE countries. The main risk for the SEE countries is that the crisis in the euro-area might deepen (Aghion, Harmgart, \& Weisshaar, 2010) and adverse effects on exports and capital flows might become stronger as the moderate growth of 2010 was achieved largely owing to exports to the countries of the euro-zone. The crisis of the European banking and a substantial reduction in the inflow of capital might strike hard those economies that are highly dependent on the import of capital, as is the case with Serbia.

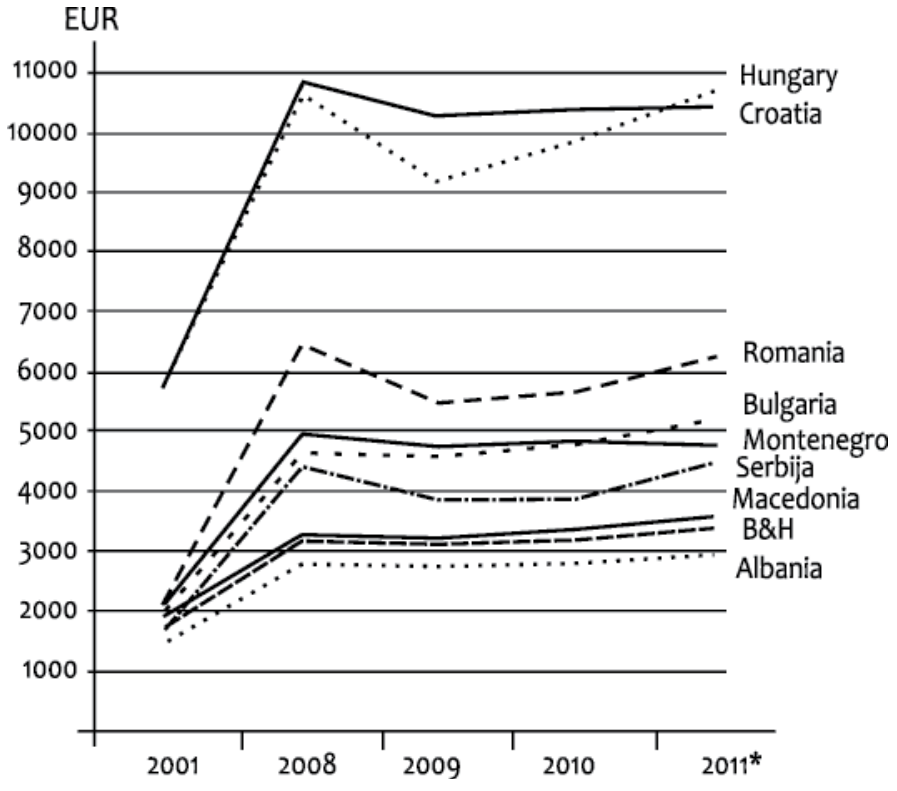

Graph 2 Crisis impact on economic growth -GDP/pc

Source: IMF, 2011

The negative effects of the debt crisis in the euro-area might reflect on the SEE economies through:

- Trade with the EU (thus impacting exports and economic growth);

- Foreign direct investments (investors from the EU are the largest source of FDI's);

- The presence of foreign banks (almost all foreign banks from the EU, with a high share of banks from Greece and Italy);

- Remittances (the countries of the euro-area present a major source of remittances).

\section{SERBIA'S DEVELOPMENT GAP}

The economic growth and development in the previous decade were aimed at creating institutional and material prerequisites for a stable development. Given the "development gap" that emerged in the last decade of the twentieth century, the average growth rate of the GDP achieved in the time period 2001-2010 (the one of 
$3.7 \%$ ) was not sufficient to help eliminate the lag - the development gap. During the pre-crisis period (until 2008), the problem of the unfavorable structure of the creation and usage of the GDP had not been resolved as domestic demand had constantly been rising faster than the output. The problem further caused the rising of the external trade deficit (lower supply of goods designed for exports and higher demand for imported goods) and, consequently, the deficit of the balance of payments current account. The deficits were covered from the inflow of foreign capital (a surplus in the financial section of the balance of payments). Over the past decade, the external debt of the country has continually been rising.

The development "transition gap" of Serbia is characterized by the following macroeconomic imbalances:

- A high share of domestic consumption in the GDP;

- An inadequate volume and an unfavorable structure of the gross fixed capital formation, as well as the share in the GDP (around 20\%);

- A rising budget deficit;

- A high foreign trade deficit with an insufficient volume and an inadequate structure of exports, as well as an inadequate share in the GDP (around $30 \%)$;

- A constant deficit of the current account of the balance of payments;

- A high share of the public debt in the GDP (around 45\%) - the Budget System Law defines the upper limit of the public debt ( $45 \%$ of the GDP);

- A constant rise and a high share of the external debt in the GDP (73.6\%). According to the World Bank's methodology, a country is over-indebted if the share of its external debt in the GDP is larger than $80 \%$.

\section{The gap: the output - domestic demand}

The main characteristic of the structure of the GDP usage is a high share of final consumption and an inadequate share of the gross fixed capital formation. During the pre-crisis time period, final consumption was rising faster than economic growth and its share in the GDP stood at as much as $98 \%$, while the share of investments was at about $20 \%$, i.e. domestic demand surpassed the total output by about $20 \%$. The highlevel final consumption led to an increase in imports.

Due to an inadequate share of the export of goods and services in the GDP (around 30\%), the external trade deficit rose, and so did the deficit of the current account of the balance of payments. In the time period of the crisis, a change to the relation between the output and domestic demand occurred. In 2010, the investment consumption and export demand increased, while final consumption was still in the negative zone. Despite the recovery of the investment activity, their share in the GDP $(19 \%)$ was still inadequate for a faster recovery of the country.

\section{Two key macroeconomic deficits}

The transition period is marked by a rising deficit of the consolidated balance of the state sector (the share of the deficit in the GDP in 2006 was 1.6\% and in 2011 it was at $4.5 \%$ ), which was financed through borrowing on the domestic and international capital markets. Because of the recession blows in 2009, the deepening of the deficit of the government sector occurred, induced by the economic downturn (a drop in tax revenues), which was to some extent alleviated in the second half of $2010(4.4 \%)$. The then current public consumption was lower, which gave room for fiscal incentives, i.e. subsidies and "soft" budget loans for the corporate sector and households.

Throughout the entire transition period after 2001, the economy has been faced with the external misbalance caused by the rising external trade deficit financed through loans from abroad. The inflow of foreign direct investments was also partially funded through the rising deficit of the current balance. In 2009, the deficit of the current account considerably decreased in comparison with the previous time period, due to a decrease in the external trade deficit. The inflow of foreign direct investments significantly decreased in 2010 because of the economic crisis. The low level of the inflow of foreign direct investments led to the deterioration of the balance of payments developments 
given that their inflow partially covers the deficit of the balance of payments current account.

\section{STRUCTURAL IMBALANCES}

Although the average economic growth over the previous decade equaled $3.7 \%$, it was not sufficient to reach the level of 1990. A positive trend of rising growth rates was interrupted by the end of 2008, when the global economic crisis escalated (in 2009, a drop in the gross domestic product equaled $-3.5 \%$ ). The GDP of Serbia rose over the previous decade mostly owing to the sector of services (an average annual growth rate of the GVA was 7.3\%), namely: information and communication (the growth rate of $15.1 \%$ ), wholesale and retail trade $(9.8 \%)$, and financial activities and insurance $(6.1 \%)$. In the time period 2001-2010, the industrial sector had no growth in fact (a zero growth), i.e. industry was hit the hardest by the recession (the drop of the manufacturing industry in 2009 equaled $-11.8 \%)$.

The transition period is marked by deteriorating structural imbalances, i.e. a change of the structure of the total newly-created value for the benefit of the sector of non-tradable goods. The global recession only further deepened the existing disproportions. The sector of services managed to increase its contribution to the GDP growth by 11.7 percentage points, while, on the other hand, the share of agriculture in the GDP fell

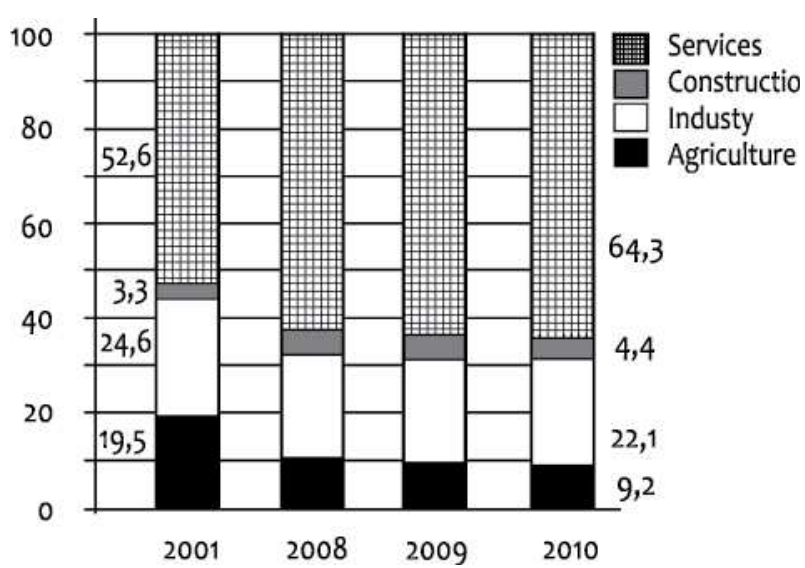

Graph 4 Sectoral structure of GVA

Source: Izveštaj o razvoju Srbije 2010

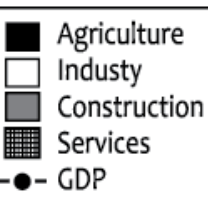

Graph 3 Sectoral dynamics of economic growth

Source: Izveštaj o razvoju Srbije 2010 . . .

.


by $10.3 \mathrm{pp}$ and the share of the manufacturing industry - by 5.9 pp. Given the importance of the industrial multiplication factors, i.e. that one newly-created job in the sector of industry produces up to 5 new jobs in other sectors of an economy, the problems that the Serbian economy is being faced with are becoming apparent.

In comparison with the countries in the region, the economic activity of Serbia over the past decade has been at a low level. The economic growth of Serbia considerably lags behind the economic growth of Romania and Hungary, and somewhat less behind that of Croatia and Bulgaria. The analysis of the GDP per capita leads to a similar conclusion: most countries in the region have a higher GDP per capita, and Croatia and Hungary more than 2 times higher.

The situation is the most difficult in the manufacturing industry. The tendency of crumbling shares of industry in the gross value added in many developed countries is not a rare phenomenon. However, differently from them, all transition economies (with the exception of Croatia and Serbia) boast of the constant high share of industry in the GVA. In order for the trend of a relative decline in the GVA of industry to be interrupted and see a substantial growth, it is essential that numerous structural reforms should be undertaken and gross fixed capital investments (production investments) be realized, while there is a need for high-tech and export products to develop. The transition experiences of others clearly show that almost all the countries of SEE must build a new industrial structure.

\section{SECTORAL REALLOCATION OF GROWTH FACTORS}

Economic growth is heavily determined by a country's ability to continually direct its resources to dynamic sectors as a response to technological changes and changes to consumer demand. This process of adjustment is linked to structural changes, i.e. the reallocation of funds (labor and capital) from one business activity to another, from the low-levelproductivity sectors to higher-level ones. Economic growth also leads to changes to the production structure of an economy, while the reallocation of capital and employees is an important factor of productivity growth.

Over the last decade, the structure of the gross value added of the Serbian economy changed for the benefit of the sector of services, whereas the sectoral contribution of the primary sector halved. The

Table 3 Sector reallocation of growth factors in the Serbian economy

\begin{tabular}{|c|c|c|c|c|c|c|c|c|}
\hline & \multicolumn{3}{|c|}{ GVA } & \multicolumn{3}{|c|}{ Employment } & \multicolumn{2}{|c|}{$\begin{array}{c}\text { Average annual growth } \\
\text { rate } 2002-2010\end{array}$} \\
\hline & $\begin{array}{c}\text { share } \\
2010\end{array}$ & $\begin{array}{c}\text { change } \\
2001-2008\end{array}$ & $\begin{array}{c}\text { change } \\
2008-2010\end{array}$ & $\begin{array}{c}\text { share } \\
2010\end{array}$ & $\begin{array}{c}\text { change } \\
2001-2008\end{array}$ & $\begin{array}{c}\text { change } \\
2008-2010\end{array}$ & GVA & Employment \\
\hline Agriculture & 9.2 & -9.1 & -1.2 & 2.8 & -1.4 & -0.3 & 0.3 & -7.9 \\
\hline Industry & 22.1 & -2.7 & 0.1 & 28.4 & -9.2 & -2.6 & 0.02 & -6.5 \\
\hline Construction & 4.4 & 2.2 & -1.1 & 5.5 & 0.3 & -0.5 & 7.0 & -3.2 \\
\hline Trade & 11.1 & 4.6 & -1.1 & 13.8 & 2.5 & -0.02 & 9.5 & -0.6 \\
\hline Transport & 5.8 & 0.9 & 0.5 & 6.6 & -0.2 & 0.1 & 3.0 & -3.0 \\
\hline $\begin{array}{l}\text { Financial ac- } \\
\text { tivities and real } \\
\text { estate }\end{array}$ & 16.9 & -2.4 & 2.2 & 3.1 & 0.4 & 0.4 & $3 \cdot 3$ & 0.5 \\
\hline Other services & 30.6 & 6.5 & 0.6 & 39.9 & 7.7 & 2.9 & 3.6 & 0.6 \\
\hline Total & 100.0 & - & - & 100.0 & - & - & 3.1 & -2.8 \\
\hline
\end{tabular}


structure of employees in Serbia's economy is also dominated by the sector of services. In comparison with 2011, the share of employees of the service sector rose from $49.6 \%$ to $63.4 \%$ in 2010. In relation to 2001, the number of employees in the area of agriculture halved $(-52.4 \%)$, while the rate of the employment decline in Industry exceeds the average of the economy by almost two times (-43.0\% vs. $-22.7 \%)$. In industry and construction, more than 345,000 employees were laid off (in Agriculture around 41,000; in Services around $11,000)$.

Productivity measured with the ratio of the GVA and employment in 2001-2010 increased by $5.6 \%$. The application of Syrquin's methodology involves the disaggregation of productivity growth to two segments, namely: the intra-sectoral profit (the first addend) and the inter-sectoral employment shift (the second addend). The first is the so-called "productivity effect" because of changes to productivity that occur within each of the sectors; the second concept rests on the "reallocation effect", i.e. depends on the movement of workers through sectors that differ by productivity. The methodology is based on the identity equation (Syrquin, 1984):

$$
\xi_{\mathrm{L}}=\sum_{\mathrm{i}} \theta_{0}\left[\left(\hat{\mathrm{X}}^{\mathrm{i}}-\hat{\mathrm{L}}^{\mathrm{i}}\right)+\left(\theta_{0}^{\mathrm{i}}-\varepsilon_{0}^{\mathrm{i}}\right) \hat{\mathrm{L}}_{\mathrm{i}}\right]
$$

$\xi_{L}$ - productivity growth in an entire economy

$\widehat{X}$ - the growth rate of the GVA of the i sector

$\widehat{\mathrm{L}}$ - the growth rate of the employment of the i sector

$\theta$ - the share of sector $i$ in the GVA

$\varepsilon$ - the share of sector $i$ in employment.

The productivity effect with a negative pre-sign shows that the productivity rise is higher than the rise in the output, i.e. the output goes down at the rate higher than the rate of the fall of employment. By analogy, the effect of the reallocation lower than zero can be a consequence of two factors: either the employment growth rate is negative or the share of employment is higher than the share of the output. Generally speaking, the sectors whose share of the GVA was higher than the share of employment had the most dynamic growth.

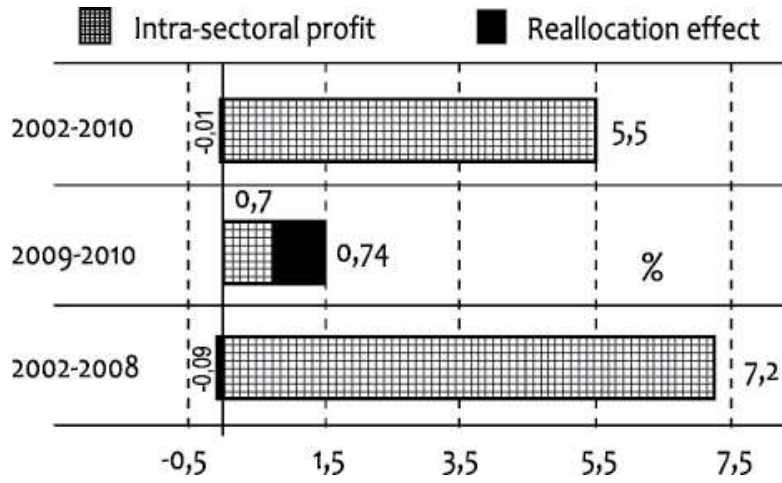

Graph 5 Growth rates of productivity in economy

Source: Author's calculations on the basis of APR

The decomposition of productivity growth also specifies a sectoral contribution to growth. The rise in the productivity in Serbia during the time period 20022010 was determined by the rise in the productivity of the service sectors (services total 63\%; Trade, Transport and Financial and real estate activities $40.4 \%$ ), while Industry contributed with $33 \%$.

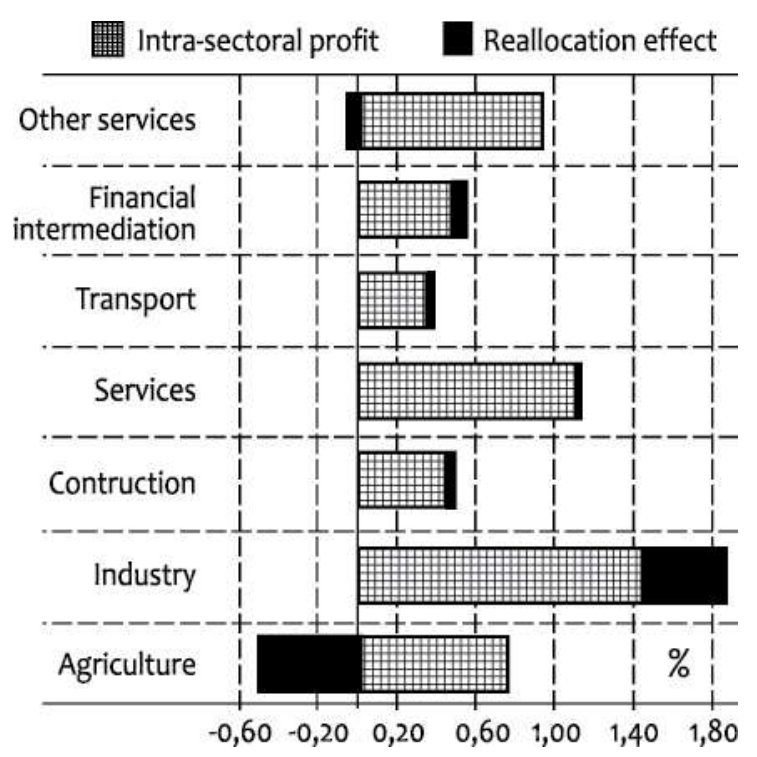

Graph 6 Decomposition of productivity growth 2002-2010

Source: Author's calculations on the basis of APR 
The transition productivity growth in the time period 2002-2010 of 5.6\% is based on "the productivity effect", i.e. an intra-sectoral profit. The contribution of labor reallocation amongst the sectors is marginal at an overall level $(-0.01 \%)$. In the early transition years, a surplus of employees was a characteristic of all the sectors of the economy, and the resolution of this problem through the process of the privatization of social assets, the restructuring of large systems and public companies, and the realized structural reforms has not led to an adequate labor reallocation.

The reallocation effect had a positive impact on the productivity growth of the following sectors; Industry, Construction, Trade, Transport, and Financial, insurance and real estate activities, while the reallocation effect was negative in the sectors of Agriculture (as a consequence of the negative growth rate of employment) and Other services (due to a larger share of employment than the share of the GVA).

In the post-crisis period (2009-2010), the GVA and employment registered negative growth rates (an

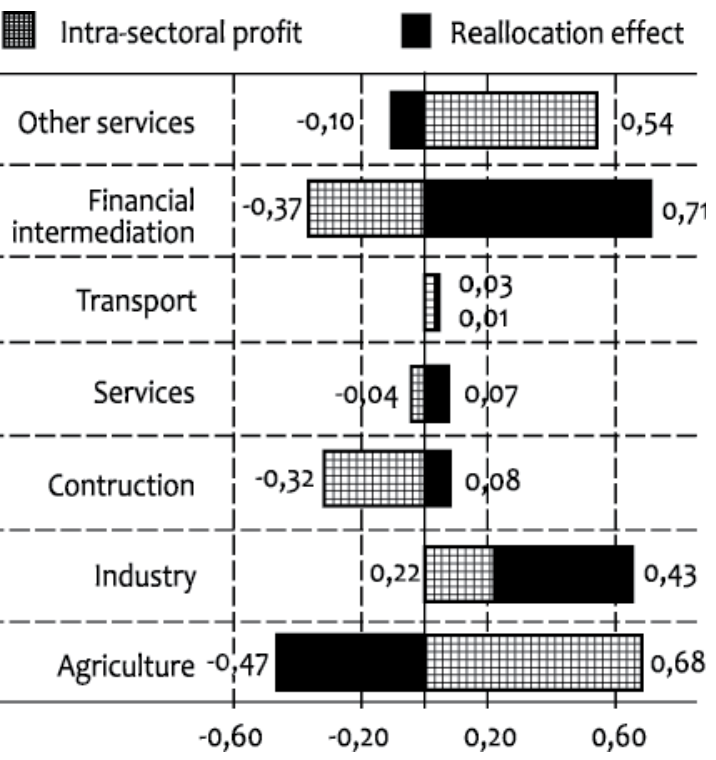

Graph 7 Decomposition of productivity growth 2009-2010

Source: Author's calculations on the basis of APR average annual drop of $-1.2 \%$, i.e. $-2.6 \%$ ). Due to a steeper drop in employment than the GVA, the productivity rose by $1.5 \%$. The greatest contribution to the productivity growth in the post-crisis period was made in the sectors of Industry $(44 \%)$ and Financial, insurance and real estate activities (23\%). The productivity growth in industry was based on the reduction in the number of workers. In comparison with 2001, the number of employees in this sector went down by more than 320,000 employees. The economic crisis further accelerated the incomplete process of the transition and restructuring of companies employment in industry in 2010, compared to 2008, went down by about 58,700 workers i.e. by $-13.3 \%$ (in the economy, by 73,820 i.e. $-5.2 \%$ ). The reallocation effect in this recession period gains momentum - a portion of dismissed workers was absorbed by the service sector. The average annual growth rate of employment in the time period 2009-2010 in the sector of Financial, insurance and real estate activities equaled $5.2 \%$. The GVA rose at a rate lower ( $+3 \%$ ) than employment, which produced a moderate rise in the productivity of this sector as the intra-sectoral profit was negative $(-0.37 \%)$. In the post-crisis period, productivity only fell in the sector of Construction.

The sector of services was the most resistant to the effects of the economic crisis - employment in comparison with 2008 was up by 2,036 workers $(+0.2 \%)$, while the average annual growth rate of the GVA of the services in the time period 2009-2010 was $+1.2 \%$ (in Industry, there was a drop of $-5.9 \%$ ). The rise in employment in the service sector in the time period of the crisis (2008-2010) was determined by the rise in the number of workers in the six knowledge-based service sectors, namely: Financial and insurance activities; Expert, scientific and technical activities; Administrative and secondary service activities; Health care and social protection; Art, entertainment and recreation, and Education, which neutralized the decline in employment in the sectors of Wholesale and retail trade $(10,430)$, Transport and storage $(3,152)$, Accommodation and nourishment services $(2,781)$, Information and communication (821), and Other service activities (661).

The continuation of the reforms in the sector of public companies, resolving the status of large industrial loss- 
makers, as well as the introduction of new technologies and professions, required by a modern market economy, suggest that the reallocation of employment to the tertiary sector and its positive effect on the rise in the overall productivity of Serbia are yet to come.

\section{POST-CRISIS STRUCTURAL TRANSFORMATIONS}

The recession waves in the time period 2009-2011 led to the downward corrections of the macroeconomic growth projections of the main aggregates by 2020; however, the idea that it is essential structural changes and macroeconomic policies conducive to industrial development that should be undertaken was only reiterated as a development imperative. The modified projections of the major macroeconomic aggregates of the Post-crisis model (USAID, 2010) of the economic growth and development of Serbia in the time period 2011-2020 are based on an average rate of economic growth for 2012-2020 of $4.3 \%$. In terms of structural changes, the growth of the tradable economic sector (industry, construction, and agriculture) would, on average, be at $4.6 \%$ at an annual level, while the sector of services would have a somewhat lower average growth of $3.7 \%$. The key parameters that could impact structural changes in the economy are:

- A substantial rise in investments (the share in the GDP to go up from $19.7 \%$ in 2012 to $24 \%$ in 2020);

- A considerable rise in exports (the share in the GDP to go up from $35.9 \%$ in 2012 to $58.3 \%$ in 2020);

- A reduction in the external trade deficit (the share in the GDP to go down from $14.9 \%$ in 2012 to $11.3 \%$ in 2020);

- A reduction in the deficit of the current transactions in the balance of payments (the share in the GDP to go down from $8.4 \%$ in 2012 to $4.5 \%$ in 2020).

The speeding-up of the economic growth is projected for the time period 2015-2020 (an average growth rate of the GDP is 5\%) and it is based on a considerable boost of the investment activity (coupled with a larger share of tradable goods in the structure of the GDP), exports, and consumption. In order to see the share of the gross fixed capital formation in the GDP rise to $24 \%$ in 2020, it takes for an average real rate of investment growth to be at $8.5 \%$ (in 2012-2020). The growth would be twice as big as the GDP growth, and much faster than the growth of overall domestic demand.

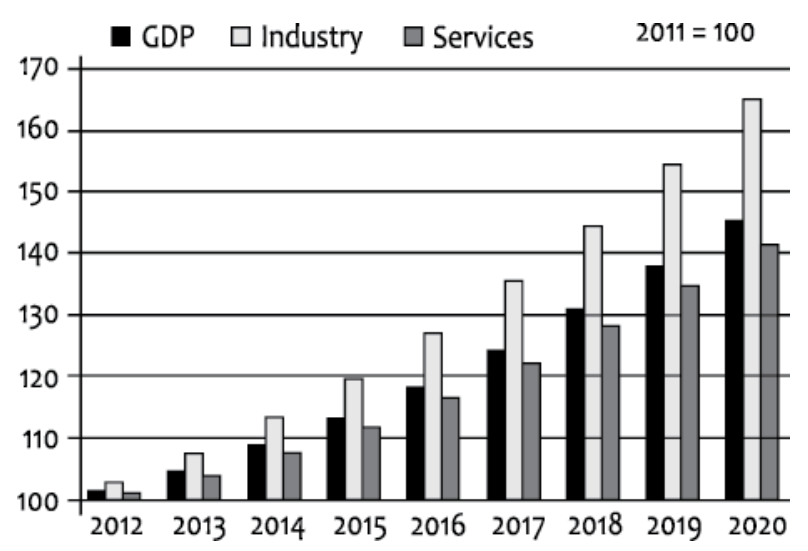

Graph 8 Projections of structural changes - cumulative indexes of real growth

Source: Author's calculations

The assumptions of the reduction in the foreign trade deficit indicate that a boost in exports will be essential in the time period to come as well as that it will be a substitute for the lacking foreign capital that will be ever more difficult to attract. An average growth rate of exports in the time period 2012-2020 would be at $11.7 \%$, while an average growth rate of imports would be at $9.4 \%$. With such developments of exports and imports, the external trade deficit would equal $11.3 \%$ of the GDP at the end of the period.

The growth of final consumption in the following period is linked to a considerable rise in investments. A lower rise in final consumption ensures a rise needed in investments. Taking into account the assumption of the reduction in the deficit of the current transactions in the balance of payments, it is assumed that internal demand will rise more slowly than the GDP. An average estimated growth of consumption is 2.9\%; however, final consumption in 2011-2014 would stagnate (personal consumption would rise moderately 
and public consumption would slightly go down); only after 2014 are higher growth rates likely to appear - an average growth rate of personal consumption in the time period 2015-2020 would be $4.4 \%$ and an average growth rate of public consumption $3.2 \%$. In the time period 2012-2020, one could expect to see a decrease in the share of public consumption in the GDP (of 3.1\%). The share of final consumption in the GDP would go down from $95 \%$ in 2011 to $86.4 \%$ in 2020 .

The key macroeconomic policies should be in line with the new macroeconomic model of economic growth, primarily regarding the fiscal, monetary, investment, and employment policies. An industrial policy is particularly accountable when the realization of structural changes in the manufacturing industry is concerned.

The primary objective of the industrial policy is to prop structural changes and all the activities that help the more efficient functioning of the market and the creation of a more favorable business environment, whereby direct interventions are only permitted in the cases of deficient markets (Chang, 2009; Haraguchi \& Rezonja, 2011; Jakopin \& Bajec 2012). Government intervention measures, undertaken as part of the industrial policy, must be of a limited term, i.e. they must be prevented from deforming market relations extensively after having fulfilled their function. Through special intervention programs, the state should influence the establishment of a new industrial structure - through the mechanisms of the state aid, it will stimulate the development of the export-oriented and competitive sectors as well as those generating a high value added, namely:

- Food industry

- Industry of transport equipment

- ICT

- Metal complex

- Health industry

A well-coordinated industrial policy involving balanced horizontal and vertical measures in the listed priority industrial areas should result in a multiplicative impact on an overall industrial development based on the knowledge and application of innovations, particularly in the area of the activation of the development potentials of the leading export-oriented companies. The new industrial structure should be included in the modern market flows more efficiently primarily because of: a) opportunities for the creation of new, permanent jobs; b) a rise in exports; c) the creation of new technological-production chains; and d) the development of competitive industrial clusters (Jakopin, 2010).

\section{CONCLUSION}

The recession has validated the findings on the regularity of the market cycles and on systemic macroeconomic imbalances. For a number of years, the transition economies in SEE have been overheated and faced with rising current account deficits, increasing indebtedness, and imbalanced exchange rates. Macroeconomic effects are apparent: all the countries are faced with a higher external debt. Systemic imbalances, primarily those of structural character, have surfaced.

Serbia lags behind reform processes a lot (it is even below the average of the SEE countries), particularly in the key segments such as: the privatization and restructuring of large enterprises, the competitiveness policy, and infrastructural reforms (EBRD, 2011; WEF, 2011). Only structural reforms can lead to a higher efficiency (Porter, 2008) and a faster economic growth (e.g. the Baltic States and Poland, as they have completed more rapid structural reforms). Resulting from unrealized structural changes, the biggest problem is a high unemployment rate that represents a special burden from the social and development perspective (Jakopin, 2010).

The key issue from the aspect of structural changes is: has the transformation model of the Serbian industry contributed to the sectoral reallocation of resources as an important source of growth and a deciding factor in boosting overall productivity? What was the transition growth of productivity based on? The productivity growth was mainly based on the "productivity effect", i.e. an intra-sectoral profit, while the "reallocation effect" was marginal in all the sectors, except for the sector of services (in Romania, the contribution of the 
reallocation effect was $0.57 \%$, in Croatia $0.38 \%$, and in Slovenia $0.19 \%$ ). The minimal impact of the reallocation of labor can be ascribed to the fact that reallocation within the sectors still prevails over reallocation among the sectors. The structural changes undertaken through the process of the transformation of the social capital and the restructuring of large systems and public companies have not led to an adequate labor reallocation.

Taking into account the research results, the creators of the economic policy should put structural changes to the economy and an increase in labor productivity that will be based on the reallocation element in the center of the new model of economic growth. This is essential as the Serbian economy is about to see the 'second generation' of reforms, amongst which the most important one is the reform of the public sector and the restructuring of vitally important public companies. In the medium run, the greatest accountability rests on industrial policies.

The structural changes in the majority of transition economies have contributed to the growth of the industrial output and exports, and the lifting of the entire industry to a higher level. The major role in the process of boosting exports was played by the EU market, not only because of the geographic and location factors but also for the fact that the new EU member states have comparative advantages in this market. The analyses suggest that accession to the EU had a positive effect on the speed of structural changes in all transition economies.

\section{REFERENCES}

Aghion, Ph., Harmgart, H., \& Weisshaar, N. (2010). Fostering growth in CEE countries: a country-tailored approach to growth policy. EBRD: Working Paper, 118.

Candeias, M. (2010). Krise der Privatisierung. In: They gonna privatize the Air. Privatisierung, Kapitalismus und Widerstand. Berlin: Antifaschistische Linke.

Chang, H. (1993). The political economy of industrial policy in Korea. Cambridge Journal of Economics, 17, 131-157.

EBRD. (2011). Transition Report 2011.
European Commission. (2011a). European Competitiveness Report 2011. DG for Enterprise and Industry. Brussels.

European Commission. (2011b). Member states competitiveness performance and policies 2011. DG for Enterprise and Industry. Brussels.

Haraguchi, N., \& Rezonja, G. (2011). Emerging Patterns of Manufacturing Structural Change. UNU World Institute for Development Economics Research (UNU-WIDER): Working Paper, 43.

International Monetary Fund. (2011). The World Economic Outlook: Slowing growth, rising risks. Washington DC.

Jakopin, E. (2010). Industrial Transformation: Key to Economic Growth. Ekonomika preduzeća, 65(1-2), 67-80.

Jakopin, E. (2011). Strukturne promene: gorki lekovi. Biznis $i$ Finansije, Novembar, 32.

Jakopin, E, \& Jurij, B. (2012). Structural transformations - A development imperative. Ekonomika preduzeća, 65(1-2), 63-78.

Lin, Y. J. (2010). New Structural Economics - A Framework for Rethinking Development. The World Bank. WPS5197.

Mencinger, J. (2011). Slovenija - između kolapsa socijalizma i krize kapitalizma. Belgrade, Srbija: Friedrih Ebert Fondacija.

Министарство финансија. (2011). Извештај о развоју Србије 2010. Београд.

OECD. (2001). Structural change and growth: Trends and policy implications. Directorate for Science, Technology and Industry. Paris.

Polanyi, K. (2003). The Great Transformation. Beograd, Srbija: Filip Višnjić.

Porter, M. (2008). The Five Competitive Forces that Shape Strategy, Harvard Business Review: 25-39.

Републички завод за развој. (2011). Стратегија и политика развоја индустрије 2011-2020. Сл. гласник. Београд.

Rodrik, D. (2008). Industrial Development: Some Stylized Facts and Policy Directions. In D. O'Connor \& M. Kjöllerström (Eds.), Industrial Development for the 21st Century. Hyderabad: Orion Printers.

Syrquin, M. (1984). Resource Reallocation and Productivity Growth. In M. Syrquin, L. Taylor, \& L.E. Westphal (Eds.), Economic Structure and Performance. New York: Academic Press.

USAID. (2010). Postkrizni model ekonomskog rasta i razvoja Srbije. Beograd. 
World Bank. (2011). Doing Business 2012. Washington DC.

World Economic Forum. (2011). The Global Competitiveness Report 2011/2012. New York: Oxford University Press.
http://www.apr.gov.rs/Регистри/Финансијскиизвештаји ибонитет.аspx

Received 21 June 2012, after one revision, accepted for publication 9 July 2012

Edvard A. Jakopin is a Head of National Development Department, the Ministry of Finance, the Republic of Serbia. He received his Ph.D. degree from the Faculty of Economics, University of Belgrade, Serbia. He has written numerous expert and scientific papers in the field of macroeconomics, economic development planning, structural changes, competitiveness, and regional modeling. 


\title{
POSTKRIZNA REALOKACIJA FAKTORA RASTA
}

\author{
Edvard Jakopin* \\ Ministarstvo finansija Republike Srbije - Sektor za nacionalni razvoj
}

\begin{abstract}
Globalna recesijajejošjednom potvrdila ekonomsku zakonitost da privredni rastnije mogućbez kontinuiranih strukturnih promena. Tranzicioni modeli realokacije faktora rasta pokazali su svu svoju neefikasnost pod naletom recesionih udara. Istraživanje tranzicionog rasta produktivnosti pokazalo je da se produktivnost bazirala, pre svega, na "unutarsektorskoj dobiti", a ne na tzv. "realokacionom efektu". Kompletno područje zemalja Jugoistočne Evrope (JIE) suočeno je sa sistemskim makroekonomskim neravnotežama, koje su, primarno, strukturnog karaktera. $S$ druge strane, komparativna analiza reformskih iskustava pokazuje da tranzicioni rezultati zavise kako od brzine sprovedenih reformi tako i od startne pozicije. Istraživanja su jasno ukazala da je održiv privredni rast bio veći u onim tranzicionim ekonomijama u kojima su reforme bile brže od onih sa strategijom postepenog razvoja. Kriza je u prvi plan istakla značaj industrijskih politika koje su dugo i u teorijskom i u praktičnom smislu bile marginalizovane. Težište postkrizne realokacije faktora rasta, u novom modelu privrednog rasta, neophodno je usmeriti ka strukturnim promenama u produktivnije izvozne sektore prerađivačke industrije.
\end{abstract}

Ključne reči: realokacija faktora rasta, makroekonomske neravnoteže, razvojni jaz, postkrizne strukturne transformacije

JEL Classification: O11, O47, L16, P21, O25, H62, J24

\section{UVOD}

Tranzicioni model baziran na privatizaciji društvene svojine suočio se sa krizom svoje opravdanosti (Candeias, 2010). Recesioni naleti pojačali su negativne efekte procesa privatizacije (ogromna nezaposlenost, socijalni troškovi, pogoršavanje uslova rada), promenili društvenu klimu o efikasnosti privatizacije, povećali kritičku distancu. Dalja privatizacija javnih dobara nailazi na posebno veliki otpor. Kriza legitimnosti

\footnotetext{
* Korespondencija: E. Jakopin, Ministarstvo finansija - Sektor za nacionalni razvoj, 11000 Beograd, Srbija; e-mail: edvard@yubc.net
}

procesa privatizacije potiče još iz, poznatog primera, katastrofa engleske železnice, čiju je mrežu na kraju ponovo morala da preuzme država. Dok se, i pored sve većeg broja poništenih privatizacija, $\mathrm{u}$ tranzicionim državama aktuelizuju novi modeli privatizacije javnog sektora, u Evropi se razvijaju i konkretizuju alternativne koncepcije.

Tranziciono područje JIE, suočeno sa sve jačim makroekonomskim neravnotežama i recesionim udarima, ubrzano redefiniše svoje razvojne modele. Predkrizni modeli realokacije faktora rasta stvorili su veliki razvojni jaz i strukturne neravnoteže. Svi postkrizni modeli realokacije faktora rasta baziraju se na industrijskim politikama. Optimalne industrijske 
strukture razlikuju se od stepena razvoja zemlje (Lin, 2010), jer su komparativne prednosti u različitim industrijama u zavisnosti od faze razvoja (postoje trenutne i latentne komparativne prednosti).

Istraživanje ima za cilj da, na primeru srpske ekonomije, ukaže na: (a) trend i posledice makroekonomskih i strukturnih neravnoteža, (b) osnove na kojima se bazirao rast produktivnosti, odnosno, da li se tranzicioni rast produktivnosti zasnivao na "efektu produktivnosti", ili na "realokacionom elementu", (c) kvalitet tranzicione preraspodele rada, $i$ (d) osnovne parametre postkrizne strukturne transformacije i realokacije faktora privrednog rasta srpske privrede.

Uradu sepolaziod osnovnehipoteze da transformacioni model nije doprineo sektorskoj realokaciji resursa i da se tranzicioni rast produktivnosti srpske privrede nije bazirao na realokacionom efektu, što je osnovni preduslov za adekvatnu preraspodelu rada i strukturne promene. Metodološki analitički instrumentarijum uokviren je reprezentativnim makroekonomskim pokazateljima, projekcija privrednog rasta zasnovana je na kvantifikacijama novog modela privrednog rasta, dok je za analizu produktivnosti korišćena poznata Sirkvinova metodologija rasta produktivnosti.

\section{PRIVREDNI RAST}

\section{MAKROEKONOMSKE NERAVNOTEŽE}

Globalna ekonomija se ponovo nalazi u opasnoj zoni. Za razliku od 2009, ovoga puta težište problema je u Evrozoni, u mnogim razvijenim zemljama Evrope privredni rast opterećuju visoki javni deficiti i dugovi, rastuće tenzije na tržištu, intenziviranje finansijskih turbulencija i pojačano slabljenje poverenja u finansijski sistem, što se sve reflektuje na investicije i potrošnju, na hitne fiskalne konsolidacije koje opterećuju domaću tražnju i izvozne aktivnosti.

Rast domaće tražnje zaostaje za rastom BDP u većini razvijenih ekonomija Evrope. Eksterna tražnja opada skoro u celoj Evropi i verovatno će nastaviti da se kreće u skladu sa globalnim usporavanjem. Globalna finansijska tržišta zahvaćena su širenjem dužničkih kriza iz evropskih zemalja, tako da se svetska ekonomija pomera na putanju nižeg privrednog rasta.
Tabela 1 Procene realnog rasta BDP

\begin{tabular}{lcccc}
\hline & 2010 & 2011 & 2012 & 2013 \\
\hline Evrozona & 1,9 & 1,5 & 0,5 & 1,3 \\
EU-27 & 2,0 & 1,6 & 0,6 & 1,5 \\
SAD & 3,0 & 1,6 & 1,5 & 1,3 \\
Japan & 4,0 & $-0,4$ & 1,8 & 1,0 \\
Kina & 10,3 & 9,2 & 8,6 & 8,2 \\
Svet & 5,0 & 3,7 & 3,5 & 3,6 \\
\hline
\end{tabular}

Izoor: European Comission, European Economic Forecast, 2011a

Problemi najueće ekonomije na svetu: Evropska unija je najveća ekonomija na svetu sa BDP-om od 16,2 biliona dolara, veća i od američke i od kineske. Međutim, 77\% BDP-a čine usluge, a svega $20 \%$ industrija. Pored toga, recesione udare uzrokuje problem deficita tekućeg računa platnog bilansa koji se pogoršava, zbog sve većeg trgovinskog deficita. EU ima veliki trgovinski deficit sa Kinom, što je posledica strategije EU da se okrene ekonomiji znanja i da izvozi znanje, $u$ čemu su uspesi izostali, ali je, s druge strane, izgubila industriju (Mencinger, 2011).

U okviru EU, jedna grupa ekonomija je faktički izašla iz recesije, zahvaljujući značajnom rastu prerađivačke

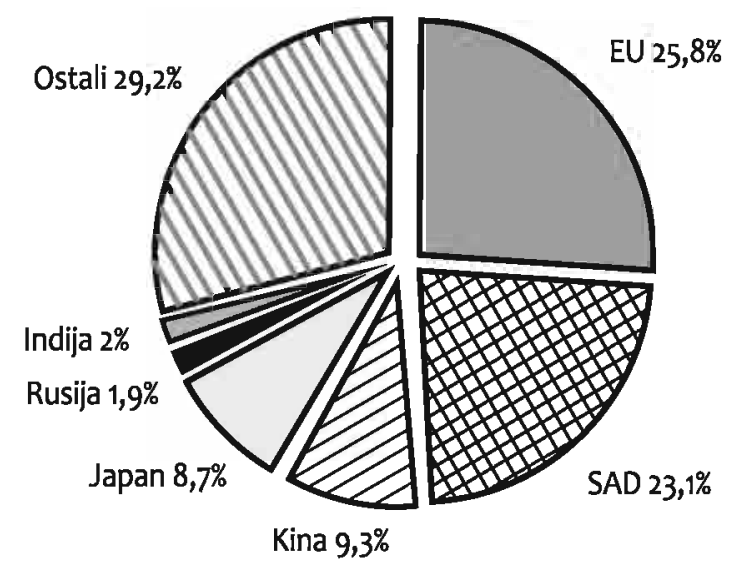

Grafikon 1 Struktura BDP sveta 2010.

Izvor: IMF, 2011 
industrije (Danska, Nemačka, Poljska, Holandija, Švedska, Švajcarska, Turska), druga grupa se nalazi u dubokoj dužničkoj krizi (Grčka, Irska, Portugalija), dok je $u$ trećoj grupi rast $u$ 2011. niži nego prosečni rast pre krize. Neke od njih imaju probleme sa rastućom nestabilnosti tržišta i rastom obaveza (Italija i Španija).

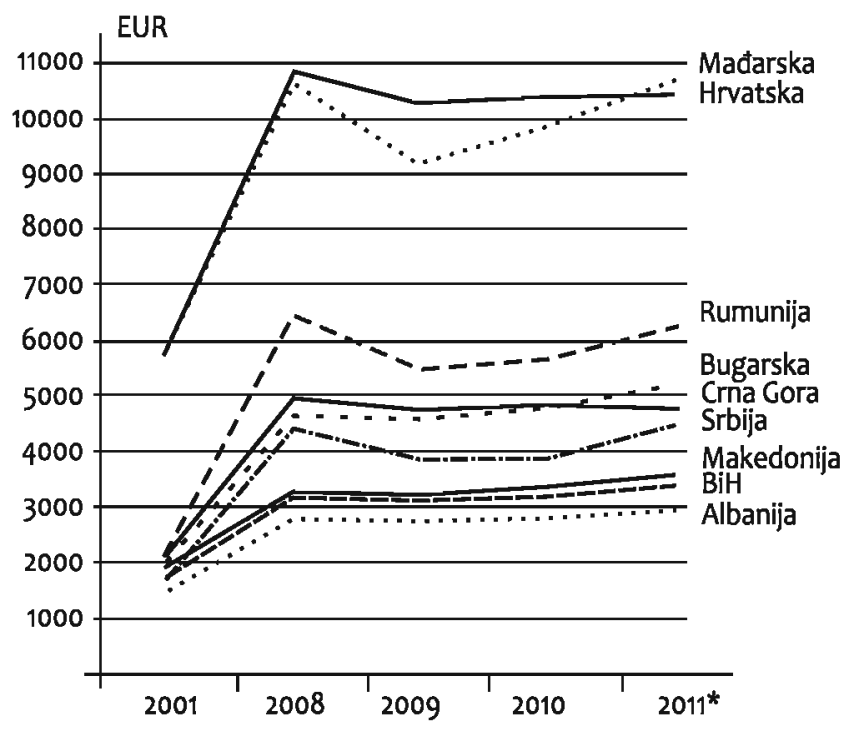

Grafikon 2 Uticaj krize na privredni rast - BDP/pc

Izvor: IMF, 2011

Refleksija recesije na tranzicione ekonomije JIE: Ekonomski oporavak od posledica globalne krize 2008/2009. u zemljama JIE počeo je 2010. i nastavljen je početkom 2011. Međutim, od drugog kvartala 2011. ekonomska situacija se pogoršala i oporavak je doveden u pitanje usled turbulencija u Evrozoni koje stvaraju velike rizike u zemljama JIE. Glavni rizik za zemlje JIE jeste mogućnost produbljivanja krize u Evrozoni (Aghion, Harmgart \& Weisshaar, 2010) i negativni uticaj na izvoz i tokove kapitala s obzirom da je skromni rast 2010. postignut uglavnom izvozom zemalja u Evrozonu. Kriza u evropskom bankarstvu i značajno smanjenje priliva kapitala može mnogo da pogodi ekonomije koje su visoko zavisne od uvoza kapitala, kao što je slučaj sa Srbijom.

Negativni uticaji krize duga u Evrozoni mogli bi se reflektovati na ekonomije zemalja JIE kroz:
- trgovinu sa EU (a time na izvoz i ekonomski rast);

- strane direktne investicije (investitori iz EU su najveći izvor SDI);

- prisustvo stranih banaka (gotovo sve strane banke su iz EU, sa visokim udelom banaka iz Grčke i Italije);

- doznake (zemlje Evrozone predstavljaju značajan izvor doznaka).

\section{RAZVOJNI JAZ SRBIJE}

Privredni rast $i$ razvoj $u$ prethodnoj deceniji odvijao se $u$ cilju stvaranja institucionalnih $i$ materijalnih pretpostavki za stabilan razvoj. S obzirom na "razvojnu rupu", koja je nastala u poslednjoj deceniji prošlog veka, ostvarena prosečna stopa rasta BDP u periodu 2001-2010. (3,7\%) nije bila dovoljna da se nadoknadi zaostatak - razvojni jaz. Predkrizni period do 2008. nije rešio problem nepovoljne strukture stvaranja i upotrebe BDP, jer je domaća tražnja konstantno rasla brže od proizvodnje. Taj problem je dalje uzrokovao rastući spoljnotrgovinski deficit (smanjena ponuda robe za izvoz i povećana tražnja za uvoznom robom), a tako i deficit tekućeg računa platnog bilansa. Deficiti su pokrivani iz priliva inostranog kapitala (suficit $u$ finansijskom delu platnog bilansa). Tokom protekle decenije spoljni dug zemlje je konstantno rastao.

Razvojni "tranzicioni jaz" Srbije karakterišu sledeće makroekonomske neravnoteže:

- visoko učešće domaće potrošnje u BDP;

- nedovoljan obim i nepovoljna struktura investicija u osnovna sredstva, kao i učešće u BDP (oko 20\%);

- rastući budžetski deficit;

- visok spoljnotrgovinski deficit, sa nedovoljnim obimom i neadekvatnom strukturom izvoza, kao i nedovoljnim učešćem u BDP (oko 30\%);

- konstantan deficit tekućeg računa platnog bilansa;

- visoko učešće javnog duga u BDP (oko 45\%) - prema Zakonu o budžetskom sistemu utvrđena je gornja granica visine javnog duga ( $45 \% \mathrm{BDP})$;

- konstantan rast i visoko učešće spoljnog duga u BDP (73,6\%). Prema metodologiji Svetske banke, zemlja 
je visoko zadužena ukoliko je učešće spoljnog duga $\mathrm{u} \mathrm{BDP}>80 \%$.

\section{Jaz: proizvodnja - domaća tražnja}

Osnovna karakteristika strukture upotrebe BDP je visoko učešće finalne potrošnje i nedovoljno učešće investicija u osnovna sredstva. U predkriznom periodu finalna potrošnja je beležila brži rast od privrednog rasta i njeno učešće u BDP je iznosilo čak $98 \%$, dok su investicije imale učešće od oko $20 \%$, odnosno, domaća tražnja je prevazilazila ukupnu proizvodnju za oko $20 \%$. Visoka finalna potrošnja uticala je na povećanje uvoza.

Usled nedovoljnog učešća izvoza robe u usluga u BDP (oko 30\%) došlo je do rasta deficita spoljnotrgovinske razmene, kao i deficita tekućeg dela platnog bilansa. $\mathrm{U}$ kriznom periodu došlo je do promene $\mathrm{u}$ odnosu proizvodnje i domaće tražnje. Tokom 2010. beleži se rast investicione potrošnje i izvozne tražnje, dok je finalna potrošnja i dalje u negativnoj zoni. I pored oživljavanja investicione aktivnosti, njihovo učešće u BDP $(19 \%)$ i dalje je nedovoljno za brži privredni oporavak zemlje.

\section{Dva ključna makroekonomska deficita}

Tranzicioni period karakteriše rastući deficit konsolidovanog bilansa sektora države (učešće deficita u BDP u 2006. je iznosilo 1,6\%, a u 2011. godini $4,5 \%$ ), koji je finansiran zaduživanjem na domaćem i međunarodnom tržištu kapitala. Usled recesionih udara u 2009. došlo je do produbljivanja deficita sektora države kao posledica pada privredne aktivnosti (smanjenje poreskih prihoda), koji je nešto ublažen u drugoj polovini 2010. (4,4\%). Tekuća javna potrošnja bila je manja što je omogućilo stvaranje prostora za fiskalne podsticaje, odnosno, subvencije i "meke" budžetske kredite privredi i stanovništvu.

Tokom celog tranzicionog perioda od 2001. privreda je bila suočena sa eksternom neravnotežom, uzrokovanom rastućim spoljnotrgovinskim deficitom, koji je finansiran kreditima iz inostranstva. Priliv stranih direktnih investicija je, takođe, jednim delom finansirao rastući deficit tekućeg bilansa. Deficit tekućeg računa u 2009. je značajno smanjen u odnosu na prethodni period usled smanjenja deficita spoljnotrgovinske razmene. Priliv stranih direktnih investicija je bio značajno smanjen u 2010. usled dejstva ekonomske krize. Nizak nivo priliva stranih direktnih investicija uslovio je pogoršanje platnobilansnih kretanja, s obzirom da njihov priliv pokriva jednim delom deficit tekućeg računa platnog bilansa.

\section{STRUKTURNE NERAVNOTEŽE}

Mada je prosečan privredni rast $u$ protekloj deceniji iznosio $3,7 \%$, on nije bio dovoljan za dostizanje nivoa iz 1990. Pozitivan trend rastućih stopa rasta bio je prekinut krajem 2008. eskalacijom svetske ekonomske krize (pad bruto domaćeg proizvoda u 2009. iznosio je -3,5\%). Za rast BDP Srbije u protekloj deceniji najzaslužniji je bio sektor usluga (prosečna godišnja stopa rasta BDV od $7,3 \%$ ), i to: informisanje i komunikacije (stopa rasta od $15,1 \%)$, trgovina na veliko i malo $(9,8 \%)$, finansijske delatnosti i delatnosti osiguranja (6,1\%). Sektor industrije u periodu 2001-2010. faktički nije imao rast (nulti rast), odnosno, industrija je bila najviše pogođena recesionim udarima (pad prerađivačke industrije $\mathrm{u}$ 2009. iznosio je $-11,8 \%$ ).

Tranzicioni period karakteriše pogoršanje strukturnih neravnoteža, odnosno, promena strukture ukupne novostvorene vrednosti u korist sektora nerazmenjivih dobara. Globalna recesija samo je produbila već formirane disproporcije. Sektor usluga je povećao svoj doprinos rastu BDP za 11,7 procentnih poena (pp), dok je, s druge strane, poljoprivreda smanjila svoje učešć u BDP za 10,3 pp i prerađivačka industrija za 5,9 pp. Imajući u vidu značaj multiplikatora industrije, odnosno, da jedno novootvoreno radno mesto $u$ sektoru industrije povlači do 5 novih radnih mesta $u$ ostalim sektorima privrede, jasno ukazuje sa kojim se problemima suočava privreda Srbije.

Privredna aktivnost Srbije $\mathrm{u}$ protekloj deceniji $\mathrm{u}$ poređenju sa zemljama u okruženju je na niskom nivou. Privredni rast Srbije značajno zaostaje za privrednim rastom Rumunije i Mađarske, a nešto manje za privrednim rastom Hrvatske i Bugarske. Analiza BDP po stanovniku ukazuje na sličan zaključak: većina zemalja u okruženju ima veći BDP po stanovniku, a Hrvatska i Mađarska čak viši 2 puta. 


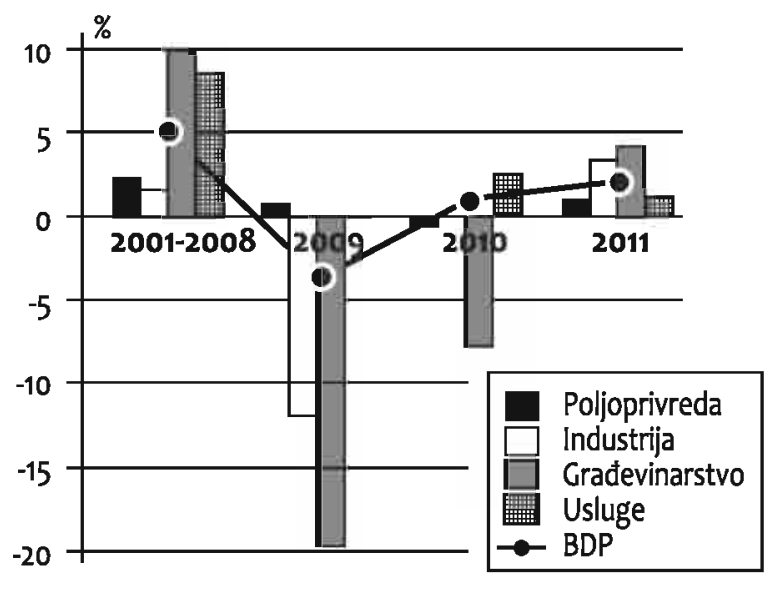

Grafikon 3 Sektorska dinamika privrednog rasta

Izvor: Izveštaj o razvoju Srbije 2010

Posebno je teška situacija u prerađivačkoj industriji. Tendencija smanjenja učešća industrije u bruto dodatoj vrednosti u mnogim razvijenijim zemljama nije nepoznat fenomen. Međutim, za razliku od njih, kod svih tranzicionih zemalja (izuzev Hrvatske i Srbije) zabeleženo je konstantno visoko učešće industrije u BDV. Da bi se trend relativnog smanjenja BDV industrije prekinuo i da bi došlo do signifikantnog rasta, nužne su brojne strukturne reforme i investicije u fiksni kapital (proizvodne investicije) kao i razvoj visokotehnoloških i izvozno orijentisanih proizvoda. Tranziciona iskustva drugih jasno ukazuju da Srbija mora proći kroz izgradnju nove industrijske strukture.

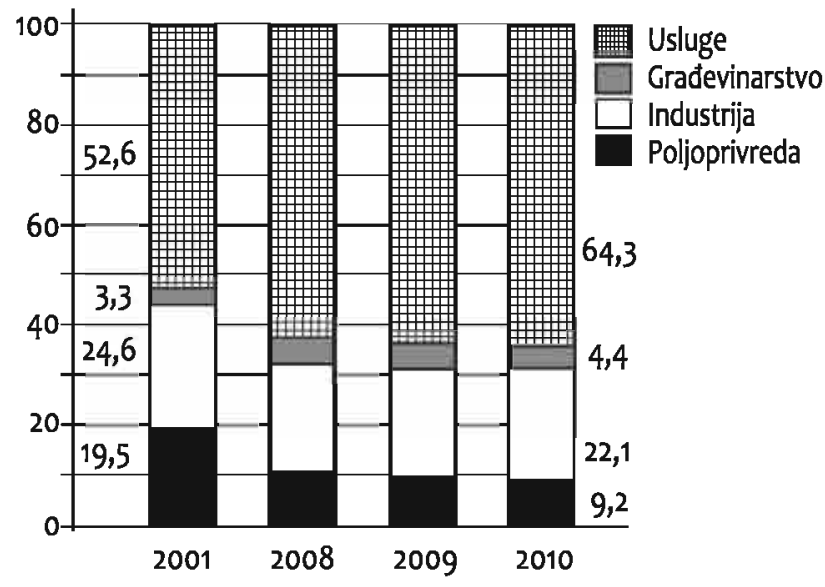

Grafikon 4 Sektorska dinamika BDV

Izzor: Izveštaj o razvoju Srbije 2010

\section{SEKTORSKA REALOKACIJA FAKTORA RASTA}

Ekonomski rast značajno je opredeljen sposobnošću zemlje da kontinuirano usmerava svoja sredstva u dinamičke sektore kao odgovor na tehnološke promene i promene u potrošačkoj tražnji. Ovaj proces prilagođavanja povezan je sa strukturnim promenama, odnosno, realokacijom sredstava (rada i kapitala) iz jedne poslovne aktivnosti u drugu, odnosno, iz sektora sa niskim nivoima produktivnosti ka onima sa višim nivoom. Ekonomski rast, takođe, dovodi do promene u proizvodnoj strukturi privrede, a realokacija kapitala i zaposlenih bitan je faktor rasta produktivnosti.

U protekloj deceniji struktura bruto dodate vrednosti srpske privrede menjala se $\mathfrak{u}$ korist sektora usluga,

Tabela 2 Stope rasta BDV industrije (u \%)

\begin{tabular}{lccccccccccc}
\hline & 2001 & 2002 & 2003 & 2004 & 2005 & 2006 & 2007 & 2008 & 2009 & 2010 & Prosek \\
\cline { 2 - 11 } EU-27 & 0,9 & $-0,1$ & 0,5 & 3,3 & 1,2 & 3,7 & 3,3 & $-2,0$ & $-12,1$ & 6,1 & 0,4 \\
Bugarska & 5,1 & 5,5 & 8,2 & 3,8 & 4,4 & 6,9 & 11,9 & 2,7 & $-6,3$ & 2,3 & 4,4 \\
Mađarska & 0,6 & 1,9 & 6,2 & 4,7 & 2,7 & 6,1 & 6,0 & $-0,1$ & $-13,1$ & 8,9 & 2,2 \\
Rumunija & 4,8 & 5,5 & 4,4 & 7,6 & 2,6 & 7,2 & 5,4 & 1,9 & $-1,4$ & 5,1 & 4,3 \\
Hrvatska & 1,7 & 4,5 & 3,6 & 4,6 & 3,3 & 3,9 & 5,5 & 1,3 & $-9,3$ & $-1,6$ & 1,7 \\
Srbija & -0.7 & 4,2 & $-2,6$ & 3,9 & 0,5 & 2,5 & 4,1 & 1,2 & $-11,8$ & 0,1 & 0,0 \\
\hline
\end{tabular}

Izvor: EUROSTAT, Izveštaj o razvoju Srbije 2010 
sektorski doprinos primarnog sektora je prepolovljen. $\mathrm{U}$ strukturi zaposlenih $\mathrm{u}$ privredi Srbije, takođe, dominira sektor usluga. U poređenju sa 2001. godinom učešće zaposlenih u sektoru usluga je povećano sa $49,6 \%$ na $63,4 \%$ u 2010. godini. U odnosu na 2001. godinu broj zaposlenih u oblasti Poljoprivrede je prepolovljen $(-52,4 \%)$, dok stopa pada zaposlenosti u Industriji skoro dva puta prevazilazi prosek privrede $(-43,0 \%$ prema $-22,7 \%)$. U Industriji i građevinarstvu bez posla je ostalo više od 345 hiljada radnika (u Poljoprivredi oko 41.000; u uslugama oko 11.000).

Produktivnost merena odnosom BDV i zaposlenosti, u periodu 2001-2010. povećana je za 5,6\%. Primenom Sirkvinove metodologije rašclanjuje se rast produktivnosti na dva dela, i to na unutarsektorsku dobit (prvi sabirak) i međusektorsko pomeranje $\mathrm{u}$ zaposlenosti (drugi sabirak) (Grafikon 5). Prvi nazivamo "efektom produktivnosti" zbog promena $\mathrm{u}$ produktivnosti unutar svakog od sektora; drugi koncept počiva na "realokacionom efektu", odnosno zavisi od kretanja radnika kroz sektore koji se međusobno razlikuju po produktivnosti. Metodologija se zasniva na jednačini identiteta (Syrquin, 1984):

$$
\xi_{\mathrm{L}}=\sum_{\mathrm{i}} \theta_{0}\left[\left(\hat{\mathrm{X}}^{\mathrm{i}}-\hat{\mathrm{L}}^{\mathrm{i}}\right)+\left(\theta_{0}^{\mathrm{i}}-\varepsilon_{0}^{\mathrm{i}}\right) \hat{\mathrm{L}}_{\mathrm{i}}\right]
$$

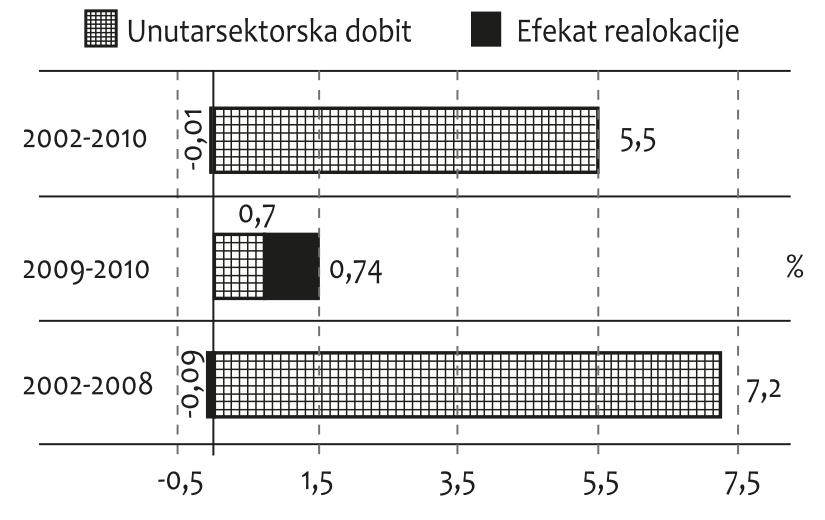

Grafikon 5 Stope rasta produktivnosti privrede

Izvor: Proračun autora na bazi podataka APR

$\widehat{\xi}_{L}$ - rast produktivnosti u čitavoj privredi

$\hat{X}$ - stopa rasta BDV sektora $\mathrm{i}$

L - stopa rasta zaposlenosti sektora i

$\theta$ - učešće sektora i u BDV

$\varepsilon$ - učešće sektora i u zaposlenosti

Efekat produktivnosti sa negativnim predznakom ukazuje da je rast zaposlenosti viši od rasta proizvodnje,

Tabela 3 Sektorska realokacija faktora rasta u privredi Srbije

\begin{tabular}{|c|c|c|c|c|c|c|c|c|}
\hline & \multicolumn{3}{|c|}{ BDV } & \multicolumn{3}{|c|}{ Zaposlenost } & \multicolumn{2}{|c|}{$\begin{array}{c}\text { Prosečna godišnja stopa } \\
\text { rasta } 2002-2010 .\end{array}$} \\
\hline & $\begin{array}{l}\text { učešće } \\
2010 .\end{array}$ & $\begin{array}{c}\text { promena } \\
2001-2008 .\end{array}$ & $\begin{array}{c}\text { promena } \\
2008-2010 .\end{array}$ & $\begin{array}{l}\text { učešće } \\
2010 .\end{array}$ & $\begin{array}{r}\text { promena } \\
2001-2008 .\end{array}$ & $\begin{array}{c}\text { promena } \\
2008-2010 .\end{array}$ & BDV & Zaposlenost \\
\hline Poljoprivreda & 9,2 & $-9,1$ & $-1,2$ & 2,8 & $-1,4$ & $-0,3$ & 0,3 & $-7,9$ \\
\hline Industrija & 22,1 & $-2,7$ & 0,1 & 28,4 & $-9,2$ & $-2,6$ & 0,02 & $-6,5$ \\
\hline Građevinarstvo & 4,4 & 2,2 & $-1,1$ & 5,5 & 0,3 & $-0,5$ & 7,0 & $-3,2$ \\
\hline Trgovina & 11,1 & 4,6 & $-1,1$ & 13,8 & 2,5 & $-0,02$ & 9,5 & $-0,6$ \\
\hline Saobraćaj & 5,8 & 0,9 & 0,5 & 6,6 & $-0,2$ & 0,1 & 3,0 & $-3,0$ \\
\hline $\begin{array}{l}\text { Finansijske delat. } \\
\text { i nekretnine }\end{array}$ & 16,9 & $-2,4$ & 2,2 & 3,1 & 0,4 & 0,4 & 3,3 & 0,5 \\
\hline Ostale usluge & 30,6 & 6,5 & 0,6 & 39,9 & 7,7 & 2,9 & 3,6 & 0.6 \\
\hline Ukupno & 100,0 & - & - & 100,0 & - & - & 3,1 & $-2,8$ \\
\hline
\end{tabular}

Izvor: Ministarstvo finanija Republike Srbije, 2011 
odnosno da proizvodnja opada po većoj stopi od stope pada zaposlenosti. Analogno tome, efekat realokacije niži od 0 može da bude posledica delovanja dva faktora: ili je stopa rasta zaposlenosti negativna ili je udeo zaposlenosti viši od udela proizvodnje. Generalno, sektori kod kojih je učešće BDV veće od učešća zaposlenosti imali su najdinamičniji rast.

Dekompozicija rasta produktivnosti, takođe, utvrđuje sektorski doprinos rastu (Grafikon 6). Porast produktivnosti u Srbiji u periodu 2002-2010. opredeljen je rastom produktivnosti uslužnih sektora (usluge ukupno 63\%, Trgovina, Saobraćaj i Finansijske delatnosti i poslovanje nekretninama 40,4\%), dok je Industrija doprinela sa $33 \%$.

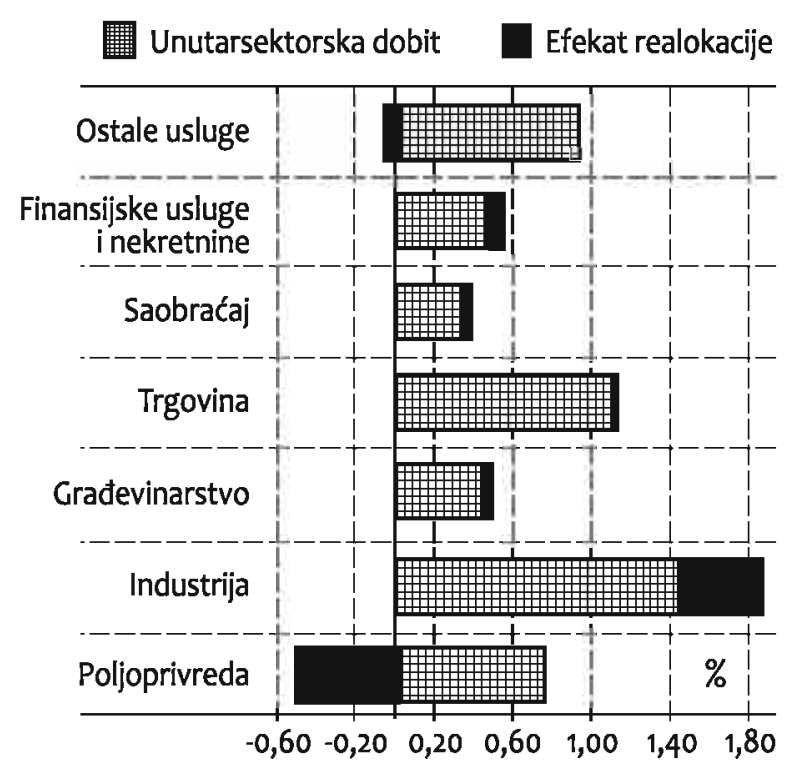

Grafikon 6 Dekompozicija rasta produktivnosti 2002-2010.

Izvor: Proračun autora na bazi podataka APR

Tranzicioni rast produktivnosti 2002-2010. od 5,6\% zasnovan je na "efektu produktivnosti", odnosno, unutarsektorskoj dobiti. Doprinos preraspodele rada među sektorima, na ukupnom nivou, je marginalan $(-0,01 \%)$. U početnim godinama tranzicije višak radnika je bio karakterističan za sve sektore privrede, a rešavanje ovog problema kroz proces privatizacije društvenog kapitala, restrukturiranje velikih sistema i javnih preduzeća i sprovedene strukturne reforme nije u dovoljnoj meri dovelo do adekvatne preraspodele rada.

Efekat realokacije se pozitivno odrazio na rast produktivnosti sektora: Industrija, Građevinarstvo, Trgovina, Saobraćaj i Finansijske delatnosti, delatnost osiguranja i poslovanje nekretninama, dok je efekat realokacije negativan $\mathrm{u}$ sektorima Poljoprivreda (kao posledica negativne stope rasta zaposlenosti) i Ostale usluge (usled većeg udela zaposlenosti od udela BDV).

U postkriznom periodu (2009-2010), BDV i zaposlenost beleže negativne stope rasta (prosečan godišnji pad $-1,2 \%$, odnosno, $-2,6 \%$ ). Zbog većeg pada zaposlenosti od BDV produktivnost je povećana za 1,5\%. Najveći doprinos rastu produktivnosti u postkriznom periodu, ostvaren je u sektorima Industrija (44\%) i Finansijske delatnosti, delatnost osiguranja i poslovanje nekretninama (23\%). Rast produktivnosti $u$ Industriji zasnovan je, uglavnom, na smanjenju broja radnika.

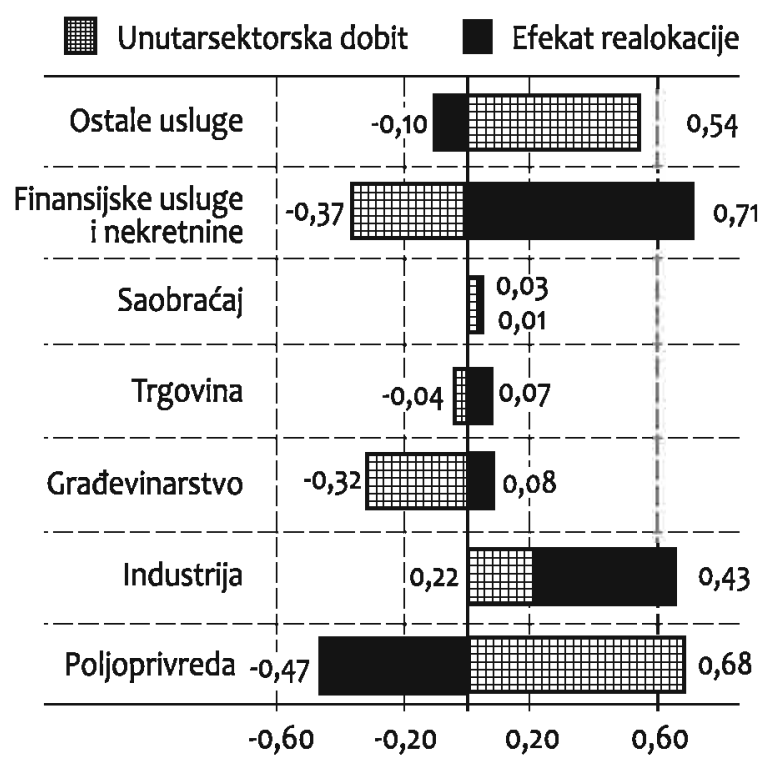

Grafikon 7 Dekompozicija rasta produktivnosti 2009-2010.

Izvor: Proračun autora na bazi podataka APR 
$\mathrm{U}$ poređenju sa 2001. broj zaposlenih u Industriji je smanjen za više od 320 hiljada radnika. Ekonomska kriza dodatno je ubrzala nedovršeni proces tranzicije i restrukturiranja preduzeća - zaposlenost u Industriji je u 2010. u odnosu na 2008. godinu smanjena za oko 58.700 radnika ili za $-13,3 \%$ (u privredi 73.820 ili $-5,2 \%$ ). Realokacioni efekat $\mathbf{u}$ ovom periodu dobija na značaju - jedan deo otpuštenih radnika apsorbovao je sektor usluga. Prosečna godišnja stopa rasta zaposlenosti 2009-2010. u sektoru Finansijske delatnosti, delatnost osiguranja i poslovanje nekretninama iznosila je $5,2 \%$. Rast BDV po nižoj stopi (+3\%) od rasta zaposlenosti, uticao je na manji rast produktivnosti ovog sektora, $s$ obzirom da je unutarsektorska dobit negativna $(-0,37)$. $\mathrm{U}$ postkriznom periodu pad produktivnosti zabeležen je jedino u sektoru Građevinarstvo.

Sektor usluga je bio najotporniji na dejstvo ekonomske krize - zaposlenost je u odnosu na 2008. veća za 2.036 radnika $(+0,2 \%)$, a prosečna godišnja stopa rasta BDV usluga $u$ periodu 2009-2010. iznosila je $+1,2 \%$ (u Industriji pad $-5,9 \%$ ). Porast zaposlenih u sektoru usluga u kriznom periodu (2008-2010.) opredeljen je rastom broja radnika u šest uslužnih sektora zasnovanih na znanju: Finansijske delatnosti i delatnost osiguranja, Stručne, naučne i tehničke delatnosti, Administrativne i pomoćne uslužne delatnosti, Zdravstvena i socijalna zaštita, Umetnost, zabava i rekreacija i Obrazovanje, što je neutralisalo pad zaposlenosti u sektorima Trgovina na veliko i malo (10.430), Saobraćaj i skladištenje (3.152), Usluge smeštaja i ishrane (2.781), Informisanje i komunikacije (821) i Ostale uslužne delatnosti (661).

Nastavak reformi u sektoru javnih preduzeća, rešavanje statusa velikih industrijskih gubitaša, kao i uvođenje novih tehnologija i zanimanja koje zahteva savremena tržišna ekonomija upućuju da realokacija zaposlenosti ka tercijalnom sektoru i njen pozitivan efekat na rast ukupne produktivnosti Srbije tek predstoji.

\section{POSTKRIZNE STRUKTURNE TRANSFORMACIJE}

Recesioni talasi 2009-2011. korigovali su naniže makroekonomske projekcije rasta osnovnih agragata do 2020. ali koncept o neophodnosti sprovodenja strukturnih promena i makroekonomskih politika u funkciji razvoja industrije samo je još više potenciran kao razvojni imperativ. Korigovane projekcije osnovnih makroekonomskih agregata iz Postkriznog modela ekonomskog rasta i razvoja Srbije 2011-2020. baziraju se na prosečnoj stopi privrednog rasta 2012-2020. od $4,3 \%$. S aspekta strukturnih promena, rast razmenjivog sektora privrede (industrija, građevinarstvo, poljoprivreda) prosećno godišnje bi iznosio $4,6 \%$, dok bi sektor usluga imao nešto niži prosečan rast od 3,7\%. Ključni parametri koji bi uticali na strukturne promene u privredi su:

- značajno povećanje investicija (povećanje učešća u BDP sa $19,7 \%$ u 2012. na $24 \%$ u 2020 .);

- značajno povećanje izvoza (povećanje učešća u BDP sa $35,9 \%$ u 2012. na $58,3 \%$ u 2020.);

- smanjenje spoljnotrgovinskog deficita (smanjenje učešća u BDP sa 14,9\% u 2012. na 11,3\% u 2020.);

- smanjenje deficita tekućih transakcija u platnom bilansu (smanjenje učešća u BDP sa 8,4\% u 2012. na $4,5 \%$ u 2020.).

Ubrzanje privrednog rasta projektovano je za period 2015-2020. (prosečna stopa rasta BDP od 5\%), koje bi bilo zasnovano na značajnom povećanju investicione aktivnosti (uz povećanje učešća razmenljivih dobara u strukturi BDP), izvoza i potrošnje. Da bi se učešće

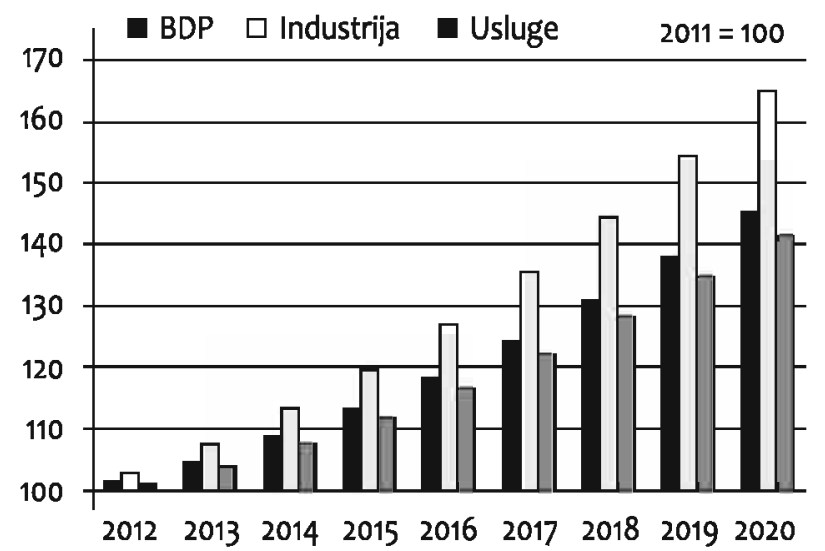

Grafikon 8 Projekcija strukturnih promena kumulativni indeksi realnog rasta

Izvor: Proračun autora na bazi Izveštaja o razvoju Srbije 2010 
investicija u osnovna sredstva u BDP povećalo na $24 \%$ u 2020. potrebno je da prosečna realna stopa rasta investicija iznosi 8,5\% (u periodu 2012-2020.). Taj rast bi bio dva puta brži od rasta BDP i znatno brži od rasta ukupne domaće tražnje.

Zbog pretpostavki o smanjenju spoljnotrgovinskog deficita, značajan rast izvoza u narednom periodu je neophodan i kao zamena za nedostajući strani kapital do koga će se sve teže dolaziti. Prosečna stopa rasta izvoza u periodu 2012-2020. iznosila bi 11,7\%, dok bi prosečna stopa rasta uvoza iznosila $9,4 \%$. Uz takvo kretanje izvoza i uvoza, spoljnotrgovinski deficit bi na kraju perioda iznosio 11,3\% BDP.

Rast finalne potrošnje $u$ narednom periodu povezan je sa značajnim rastom investicija. Niži rast finalne potrošnje omogućić potreban rast investicija. $S$ obzirom na pretpostavku o smanjenju deficita tekućih transakcija u platnom bilansu pretpostavlja se sporiji rast unutrašnje tražnje od rasta BDP. Procenjuje se prosečan rast potrošnje od 2,9\%, s tim što bi finalna potrošnja u periodu 2011-2014. stagnirala (lična potrošnja bi beležila blagi rast, a javna potrošnja blagi pad), a tek nakon 2014. beležila više stope rasta - prosečna stopa rasta lične potrošnje u periodu 20152020. iznosila bi 4,4\%, a javne potrošnje $3,2 \%$. U periodu 2012-2020. očekuje se smanjenje učešća javne potrošnje u BDP (za 3,1\%). Učešće finalne potrošnje u BDP bi bilo smanjeno sa $95 \%$ u 2011. na 86,4\% u 2020.

Shodnonovom makroekonomskom modelu privrednog rasta neophodno je da ključne makroekonomske politike budu $\mathrm{u}$ njegovoj funkciji, $\mathrm{i}$ to $\mathrm{u}$ prvom redu fiskalna, monetarna, investiciona i politika zaposlenosti. Posebna odgovornost $u$ sprovođenju strukturnih promena u prerađivačkoj industriji leži na industrijskoj politici.

Primaran zadatak industrijske politike je sprovođenje strukturnih promena i svih aktivnosti koje doprinese efikasnijem funkcionisanju tržišta i stvaranju povoljnijeg poslovnog okruženja, pri čemu su direktne intervencije dozvoljene $u$ slučajevima manjkavosti tržišta (Chang, 2009; Haraguchi \& Rezonja, 2011; Jakopin \& Bajec, 2012). Mere državne intervencije, koje se primenjuju u okviru industrijske politike, moraju biti ograničenog trajanja, odnosno, moraju što manje deformisati tržišne odnose nakon što ostvare svoju funkciju. Posebnim interventnim programima država bi trebala da utiče na stvaranje nove industrijske strukture, mehanizmima državne pomoći podsticaće razvoj izvozno konkurentnih sektora i sektora koji stvaraju visoku dodatu vrednost:

- Industrija hrane

- Industrija saobraćajnih sredstava

- IKT

- Metalski kompleks

- Industrija zdravlja.

Koordinirana industrijska politika sa izbalansiranim horizontalnim i vertikalnim merama $u$ navedenim prioritetnim industrijskim oblastima trebala bi da rezultira $\mathrm{u}$ multiplikativnom efektu na ukupan industrijski razvoj koji bi bio zasnovan na znanju i primeni inovacija, posebno $\mathrm{u}$ oblasti aktiviranja razvojnih potencijala vodećih izvozno orijentisanih preduzeća. Nova industrijska struktura bi trebala da se efikasnije uključi u savremene tržišne tokove, pre svega, zbog: (a) mogućnosti za otvaranje novih radnih mesta; (b) povećanja izvoza; (c) stvaranja novih tehnološko-proizvodnih lanaca; (d) razvoja konkurentnih industrijskih klastera (Jakopin, 2010).

\section{ZAKLJUČAK}

Recesioni talasi potvrdili su ekonomske zakonomernosti o tržišnim ciklusima i o sistemskim makroekonomskim neravnotežama. Tranzicione ekonomije u Jugoistočnoj Evropi su već duži niz godina pregrejane, suočene su sa rastućim deficitima tekućih računa, sve većom zaduženošću i neuravnoteženim kursevima. Makroekonomske posledice su jasne: $\mathrm{u}$ svim zemljama uvećan je spoljni dug. Na površinu su isplivale sistemske neravnoteže, pre svega, strukturnog karaktera.

Srbija znatno zaostaje $\mathrm{u}$ reformskim procesima (čak ispod proseka zemalja JIE), posebno, u ključnim segmentima: privatizaciji i restrukturiranju velikih preduzeća, politici konkurentnosti i infrastrukturnim reformama (EBRD, 2011; WEF, 2011). Jedino se 
strukturnim reformama dolazi do veće efikasnosti (Porter, 2008) i bržeg privrednog rasta (na primer, baltičke zemlje i Poljska, koje su izvršile brže strukturne reforme). Najveći problem, kao rezultanta nesprovedenih strukturnih promena, predstavlja visoka stopa nezaposlenosti, što iz socijalnog i razvojnog ugla ima posebnu težinu (Jakopin, 2010).

Ključno pitanje sa aspekta strukturnih promena glasi: da li je transformacini model srpske privrede doprineo sektorskoj realokaciji resursa, kao važnom izvoru rasta i presudnom faktoru porasta ukupne produktivnosti? Na čemu se bazirao tranzicioni rast produktivnosti? Rast produktivnosti uglavnom je bio zasnovan na "efektu produktivnosti", odnosno, unutarsektorskoj dobiti, dok je "realokacioni efekat" bio marginalan $u$ svim sektorima, osim u sektoru usluga (u Rumuniji je doprinos realokacionog efekta iznosio 0,57\%, u Hrvatskoj 0,38\%, Sloveniji 0,19\%). Minimalan uticaj realokacije radne snage može se pripisati činjenici da realokacija unutar sektora još uvek dominira nad realokacijom između sektora. Strukturne promene, sprovedene kroz proces transformacije društvenog kapitala i restrukturiranja velikih sistema i javnih preduzeća, nisu u dovoljnoj meri dovele i do adekvatne preraspodele rada.

Imajući $u$ vidu rezultate istraživanja, kreatori ekonomske politike u novom modelu privrednog rasta centralnu ulogu treba da daju strukturnim promenama $\mathrm{u}$ privredi i rastu produktivnosti rada koji će biti zasnovan na realokacionom elementu. To je posebno važno, s obzirom da će se srpska privreda suočiti sa "drugom generacijom" reformi, od kojih je najvažnija reforma javnog sektora i restrukturiranje vitalnih javnih preduzeća. Na srednji rok, najveća odgovornost leži na industrijskim politikama.

Strukturne promene $\mathrm{u}$ većini tranzicionih zemalja doprinele su rastu industrijske proizvodnje i izvoza, $\mathrm{i}$ podizanju kompletne industrije na viši nivo. Najveću ulogu u procesu povećanja izvoza odigralo je tržište $\mathrm{EU}$, i to ne samo zbog geografsko-lokacionih faktora, već zbog činjenice da nove članice EU na tom tržištu imaju komparativne prednosti. Analize ukazuju da je pristupanje EU pozitivno uticalo na brzinu strukturnih promena u svim tranzicionim ekonomijama.

\section{REFERENCE}

Aghion, Ph., Harmgart, H., \& Weisshaar, N. (2010). Fostering growth in CEE countries: a country-tailored approach to growth policy. EBRD: Working Paper, 118.

Candeias, M. (2010). Krise der Privatisierung. In: They gonna privatize the Air. Privatisierung, Kapitalismus und Widerstand. Berlin: Antifaschistische Linke.

Chang, H. (1993). The political economy of industrial policy in Korea. Cambridge Journal of Economics, 17, 131-157.

EBRD. (2011). Transition Report 2011.

European Commission. (2011a). European Competitiveness Report 2011. DG for Enterprise and Industry. Brussels.

European Commission. (2011b). Member states competitiveness performance and policies 2011. DG for Enterprise and Industry. Brussels.

Haraguchi, N., \& Rezonja, G. (2011). Emerging Patterns of Manufacturing Structural Change. UNU World Institute for Development Economics Research (UNU-WIDER): Working Paper, 43.

International Monetary Fund. (2011). The World Economic Outlook: Slowing growth, rising risks. Washington DC.

Jakopin, E. (2010). Industrial Transformation: Key to Economic Growth. Ekonomika preduzeća, 65(1-2), 67-80.

Jakopin, E. (2011). Strukturne promene: gorki lekovi. Biznis $i$ Finansije, Novembar, 32.

Jakopin, E, \& Jurij, B. (2012). Structural transformations - A development imperative. Ekonomika preduzeća, 65(1-2), 63-78.

Lin, Y. J. (2010). New Structural Economics - A Framework for Rethinking Development. The World Bank. WPS5197.

Mencinger, J. (2011). Slovenija - između kolapsa socijalizma i krize kapitalizma. Belgrade, Srbija: Friedrih Ebert Fondacija.

Министарство финансија. (2011). Извештај о развоју Србије 2010. Београд.

OECD. (2001). Structural change and growth: Trends and policy implications. Directorate for Science, Technology and Industry. Paris.

Polanyi, K. (2003). The Great Transformation. Beograd, Srbija: Filip Višnjić.

Porter, M. (2008). The Five Competitive Forces that Shape Strategy, Harvard Business Review: 25-39. 
Републички завод за развој. (2011). Стратегија и политика развоја индустрије 2011-2020. Сл. гласник. Београд.

Rodrik, D. (2008). Industrial Development: Some Stylized Facts and Policy Directions. In D. O'Connor \& M. Kjöllerström (Eds.), Industrial Development for the 21st Century. Hyderabad: Orion Printers.

Syrquin, M. (1984). Resource Reallocation and Productivity Growth. In M. Syrquin, L. Taylor, \& L.E. Westphal (Eds.), Economic Structure and Performance. New York: Academic Press.
USAID. (2010). Postkrizni model ekonomskog rasta i razvoja Srbije. Beograd.

World Bank. (2011). Doing Business 2012. Washington DC.

World Economic Forum. (2011). The Global Competitiveness Report 2011/2012. New York: Oxford University Press.

http://www.apr.gov.rs/Регистри/Финансијскиизвештаји ибонитет.аspx

Primljeno 21. juna 2012, nakon revizije, prihvaćeno za publikovanje 9. jula 2012.

Edvard A. Jakopin je rukovodilac Sektora za nacionalni razvoj Ministarstva finansija Republike Srbije. Doktorirao je na Ekonomskom fakultetu Univerziteta u Beogradu. Autor je brojnih naučnih i stručnih radova iz oblasti makroekonomije, planiranja privrednog razvoja, strukturnih promena, konkurentnosti, regionalnog modeliranja. 